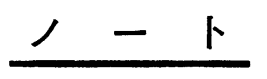

\title{
米及びいねのトコフェロール
}

\author{
加藤 秋男* ・田中章夫* - 山岡正和* - 田辺恵三** \\ * 工業技術院化学技術研究所 (茨城県筑波郡谷田部町東 1-1) \\ ** 元工業技術院化学技術研究所 (東京都練馬区 中村 1-13-6)
}

\section{Tocopherols in Rice Grains and Plants}

\author{
Akio KAto*, Akio TAnAkA*, Masakazu YamaokA*, and Keizo TAnABE** \\ * National Chemical Laboratory for Industry (1-1, Higashi, Yatabe-cho, \\ Tsukuba-gun, Ibaraki) \\ ** Former Officer of National Chemical Laboratory for Industry (1-13-6, \\ Nakamura, Nerima-ku, Tokyo)
}

Tocopherol content in the germ, pericarp and endosperm of rice grains, four leaf rice plants and mature rice plants were determined by HPLC.

The contents in the germ of rice grains, the young leaves of four leaf plants and mature rice plants were $264 \mu \mathrm{g} / \mathrm{g}, 257 \mu \mathrm{g} / \mathrm{g}$ and $134 \mu \mathrm{g} / \mathrm{g}$, respectively in dry samples.

$\alpha$-Tocopherol was the main tocopherol in young leaves and mature plants. The tocopherol content was $76 \mu \mathrm{g} / \mathrm{g}$ in the pericarp and a very little in the endosperm.

Tocopherol content in stored commercial rice bran was reduced from $275 \mu \mathrm{g} / \mathrm{g}$ to $227 \mu \mathrm{g} / \mathrm{g}$ at room temperature over a period of two months. The tocopherol content in stored mature rice plants was reduced from $134 \mu \mathrm{g} / \mathrm{g}$ to $12 \mu \mathrm{g} / \mathrm{g}$ at room temperature in three months.

\section{1 緒言}

粗製及び精製米妨油のトコフェロール含有量につい て Fisher ${ }^{1)}$ が報告している。一方，米のトコトリエ， ールについては, 玄米の抽出物中に $\alpha$-及び $\gamma$-トコト リエノールの存在が認められた2)。最近, トコフェロー ルの分析に高速液体クロマトグラフィーが使用され，米 ぬか油中の $\alpha$-トコトリエノール及び $\gamma$-トコトリエノー ルの単離と同定 ${ }^{3)}$ 並びに米ぬか油中のトコフェロール含 有量の定量4が行われた。さらに, エステル型トコフェ ロールが粗製米ぬか油に含まれていた ${ }^{5)} 。$

今回, 米のはい芽, 種皮及びはい乳, いねのトコフェ ロール含有量を HPLC を用いて定量したので, それら の結果を報告する。

\section{2 実験}

\section{$2 \cdot 1$ 試料}

米はい芽, 種皮, 及びはい乳：きよにしき(昭和 55 年, 山形県産）のはい第米製造工程で得られた種皮及び はい芽米が東京油脂工業（株）より提供された。このは 以芽米からはい芽とはい乳をか子努そりの刃を用いて分別 し, 試料に用いた。また, 品種不明の新鮮な市販米ぬか を試料に用いた。
い社：農林水産省農業技術研究所（現同省農業環境技 術研究所）で栽培した十石の四葉期のものについて, 葉 と茎に分別し，それぞれ用いた。さらに，成熟したいね は群馬県産にほんまさりの収穫時 (10 月下旬) に採取 した。

\section{$2 \cdot 2$ 抽 出}

きよにしきのはい芽, 種皮及びはい乳はソックスレー 抽出器を用い, 石油エーテルで $6 \mathrm{~h}$ 抽出した。市販米 ぬかを室温 $17 \sim 23^{\circ} \mathrm{C}$, 暗所に 1 か月 及び 2 か月貯蔵し

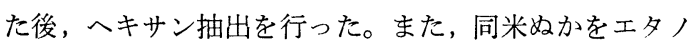
ール, ア七トン, エーテル, 石油エーテル及びヘキサン を用い,それぞれ $6 \mathrm{~h}$, ソックスレー抽出器により抽出 した。

四葉期のいねの葉と茎はそれぞれ 約 $5 \mathrm{~mm}$ 幅に切断 後室温 $17 \sim 23^{\circ} \mathrm{C}$ 付近で, ヘキサンーエタノール (1:1) を用いて抽出した。成熟したいねは幅約 $5 \mathrm{~mm}$ に切断 後上記のいねと同様に室温 $25 \sim 26.5^{\circ} \mathrm{C}$ で抽出した。各 抽出物は抽出溶剂を留去後へキサン可溶部を分取し, そ れぞれへキサンを留去し，抽出物とした。

\section{$2 \cdot 3$ 高速液体クロマトグラフィーによるトコフェ ロールの定量}

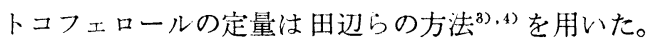
この 分析法は試料中の遊離型トコフェロール類のみ定 
量できる7)。また，トユフェロールの同定には日本電子 (株）D-300 形質量分析装置を用いた ${ }^{6)}$ 。

\section{3 結果及び考察}

\section{$3 \cdot 1$ 米のはい芽, 種皮及びはい乳のトコフェロール}

山形県産きよにしきのはい芽, 種皮及びはい乳の重量 比は $4.65: 7.04: 88.31$ で, 油分は 27.28\%, 21.19\% 及び $0.65 \%$ を示し, はい芽>種皮>はい乳の順に油分 が減少している。トコフェロール含有量ははい芽が最も 多く, 次に種皮, はい乳となり, はい乳中のトコフェロ ールは微量である。はい芽中のトコフェロールの主成分 は $\alpha$-トコフェロールであり, 全トコフェロールの $73 \%$ を占めていた。また, 種皮の場合はトコトリエノールが 全トコフェロールの 67\% を占め, $\alpha$-トコフェロールは $31 \%$ であった。一方, はい乳中に微量のトコフェロー ルが含まれていたが、このトコフェロールははい乳から はい芽の除去が完全に行われていないためか否かは明ら かでない (Table-1)。

\section{$3 \cdot 2$ 米ぬか貯蔵中のトコフェロール含有量の変化}

新鮮な市販米始かを室温 $17 \sim 23^{\circ} \mathrm{C}$, 暗所に貯蔵し, トコフェロール含有量の変化を検討した。1 か月で $9 \%$, 2 かで $17 \%$ のトコフェロール含有量が減少した。し かし, いねわらの貯蔵の場合のように, 急激なトコフェ ロール含有量の減少は認为なかった。この米妕中に 種皮のほかに米はい芽を含むため，トコフェロール含有
量 $275 \mu \mathrm{g} / \mathrm{g}$ (Table-2）を示し, 種皮中のトコフェロー ル含有量 $76 \mu \mathrm{g} / \mathrm{g}$ より多い。

また, 抽出溶媒として, エタノール，アセトン，エチ ルエーテル, 石油エーテル及びへキサンを用いて米ぬか からのトコフェロールの抽出を検討した。ソックスレー 抽出器を用い, $6 \mathrm{~h}$ 抽出した。その結果, 乾燥試料に対 してトコフェロールが 224 $292 \mu \mathrm{g} / \mathrm{g}$ 抽出され, 石油エ ーテル及びヘキサンを用いた場合が他の溶剤の場合より トコフェロールを多く抽出した。

\section{$3 \cdot 3$ いねのトコフェロール}

品種十石の四葉期に生育したいねを葉と茥に分別し て，それぞれを抽出した。抽出物は乾燥試料に対して葉 $8.90 \%$ 及び茎 $3.08 \%$ であった。葉の抽出物のトコフ エロール含有量は約 $0.3 \%$, その主成分は $\alpha$-トコフェ ロール (78\%) であった。また, トコトリエノールは約 $3 \%$ 含まれ, 種皮のトコトリエノール $(67 \%)$ と比較し て, 非常に少ない。一方, 茥のトコフェロールは葉のそ れの約 $1 / 25$ に過ぎず，トコフェロールは主に葉に含ま れていた (Table-3)。

いね(品種にほんまさり, 群馬県産)の刈り取り直後 のい衫らのエタノールーヘキサン抽出物は約 $1 \%$ であ った。この抽出物のトコフェロール含有量は約 $1.24 \%$ で, $\alpha$-トコフェロール 77\% 及び $\gamma$-トコフェロール 22 \%を主成分としていた（Table-3）。

また, 成熟したい攼わらと葉期のいねの葉のトコフ

Table-1 Free tocopherol content in germ, pericarp and endosperm of rice grain.

\begin{tabular}{|c|c|c|c|c|c|c|c|c|c|c|}
\hline \multirow{3}{*}{ Sample } & \multicolumn{9}{|c|}{ Extract $* 2$} & \multirow{3}{*}{$\begin{array}{r}\text { Tocopherol } \\
\text { content*1 } \\
(\mu \mathrm{g} / \mathrm{g})\end{array}$} \\
\hline & \multirow{2}{*}{$\begin{array}{l}\text { Yield*1 } \\
(\%)\end{array}$} & \multicolumn{4}{|c|}{$\begin{array}{l}\text { Tocopherol } \\
(\mu \mathrm{g} / \mathrm{g})\end{array}$} & \multicolumn{3}{|c|}{$\begin{array}{c}\text { Tocotrienol } \\
(/ / \mathrm{g} / \mathrm{g})\end{array}$} & \multirow{2}{*}{$\begin{array}{c}\text { Tocopherol } \\
\text { content } \\
\text { (Total, } \mu \mathrm{g} / \mathrm{g} \text { ) }\end{array}$} & \\
\hline & & $\alpha$ & $\beta$ & $\gamma$ & $\delta$ & $\alpha$ & $r$ & $\delta$ & & \\
\hline Germ & 27.28 & 709 & 64 & 90 & 5 & 39 & 54 & 5 & 966 & 264 \\
\hline Pericarp & 21.19 & 112 & 1 & 1 & 3 & 5 & 215 & 20 & 357 & 76 \\
\hline Endosperm & 0.65 & Tr. & - & Tr. & - & - & - & - & Tr. & Tr. \\
\hline
\end{tabular}

The percentage of germ, pericarp and endosperm in rice grain were $4.65 \%, 7.04 \%$ and $88.31 \%$, respectively at dry basis. Moisture of germ, pericarp and endosperm in rice grain were $9.02 \%, 11.83 \%$ and $13.21 \%$, respectively.

$*_{1}$ : Dry basis $*_{2}$ : Extracted with petroleum ether

Table-2 Free tocopherol content in the stored commercial rice bran.

\begin{tabular}{|c|c|c|c|c|c|c|c|c|c|c|}
\hline \multirow{3}{*}{$\begin{array}{l}\text { Storage } \\
\text { period } \\
\text { (month) }\end{array}$} & \multicolumn{9}{|c|}{ Extract*2 } & \multirow{3}{*}{$\begin{array}{c}\text { Tocopherol } \\
\text { content }^{* 1} \\
(/ \mathrm{g} / \mathrm{g})\end{array}$} \\
\hline & \multirow{2}{*}{$\begin{array}{l}\text { Yield*1 } \\
(0,0)\end{array}$} & \multicolumn{4}{|c|}{$\begin{array}{c}\text { Tocopherol } \\
(\mu \mathrm{g} / \mathrm{g})\end{array}$} & \multicolumn{3}{|c|}{$\begin{array}{c}\text { Tocotrienol } \\
(\mu \mathrm{g} / \mathrm{g})\end{array}$} & \multirow{2}{*}{$\begin{array}{c}\text { Total } \\
\text { tocopherol } \\
(\mu \mathrm{g} / \mathrm{g})\end{array}$} & \\
\hline & & $\alpha$ & $\beta$ & 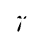 & $\hat{o}$ & $\alpha$ & $r$ & $\grave{o}$ & & \\
\hline 0 & 22.74 & 434 & 13 & 76 & 1 & 267 & 398 & 22 & 1,211 & 275 \\
\hline 1 & 22.35 & 428 & 15 & 56 & 3 & 244 & 350 & 23 & 1,119 & 250 \\
\hline 2 & 22.06 & 353 & 17 & 50 & 2 & 236 & 346 & 23 & 1,027 & 227 \\
\hline
\end{tabular}

${ }^{*} 1$ Dry basis. Moisture : $11.74 \%$ (original), $10.47 \%$ (one month) and 10.06\% (two months). Storing condition : room temperature $17 \sim 23^{\circ} \mathrm{C}$, in the dark place.

*2 Extracted with hexane 
Table-3 Free tocopherol content in rice plant.

\begin{tabular}{|c|c|c|c|c|c|c|c|c|c|c|c|}
\hline \multirow{3}{*}{ Sample } & \multirow{3}{*}{$\begin{array}{l}\text { Storage } \\
\text { period } \\
\text { (month) }\end{array}$} & \multirow{3}{*}{$\begin{array}{c}\text { Moisture } \\
\text { (\%) }\end{array}$} & \multicolumn{8}{|c|}{ Extract } & \multirow{3}{*}{$\begin{array}{c}\text { Tocopherol } \\
\text { content*1 } \\
(\mu \mathrm{g} / \mathrm{g})\end{array}$} \\
\hline & & & \multirow{2}{*}{$\begin{array}{l}\text { Yield*1 } \\
(\%)(\%)\end{array}$} & \multicolumn{3}{|c|}{$\begin{array}{l}\text { Tocopherol } \\
(\mu \mathrm{g} / \mathrm{g})\end{array}$} & \multicolumn{3}{|c|}{$\begin{array}{l}\text { Tocotrienol } \\
(\mu \mathrm{g} / \mathrm{g})\end{array}$} & \multirow{2}{*}{$\begin{array}{c}\text { Total } \\
\text { tocopherol } \\
(\mu \mathrm{g} / \mathrm{g})\end{array}$} & \\
\hline & & & & $\alpha$ & $\beta$ & $\because$ & $\alpha$ & $\ddot{r}$ & $\delta$ & & \\
\hline \multicolumn{12}{|l|}{$\begin{array}{l}\text { Four leaf stage } \\
\text { rice plant } \\
\text { (Jukoku) }\end{array}$} \\
\hline Leaves & 0 & 69.40 & 8.90 & 2,252 & 13 & 526 & -- & 92 & 5 & 2,888 & $257(79)^{* 3}$ \\
\hline Stem & 0 & 84.28 & 3.08 & 94 & $-\cdots$ & 29 & -- & - & 18 & 124 & 4 \\
\hline \multicolumn{12}{|c|}{$\begin{array}{l}\text { Mature rice plant*2 } \\
\text { (Nihonmasari) }\end{array}$} \\
\hline & 0 & 44.23 & 1.08 & 9,540 & 43 & 2,779 & & 15 & 13 & 12,443 & $134(75)^{* 3}$ \\
\hline & 1 & 8.39 & 0.87 & 3,360 & - & 2,256 & - & $\ldots$ & $\cdots$ & 5,616 & 49 \\
\hline & 3 & 7.63 & 0.87 & 674 & - & 703 & -- & - & - & 1,377 & 12 \\
\hline
\end{tabular}

*1 Dry basis *2 Sample includes leaves and stem *3 Wet basis

エロール含量はそれぞれ $134 \mu \mathrm{g} / \mathrm{g}(75 \mu \mathrm{g} / \mathrm{g}$, wet basis) 及び $257 \mu \mathrm{g} / \mathrm{g}(79 \mu \mathrm{g} / \mathrm{g}$, wet basis) であった。しか し，成熟したいねわらには葉と茎が含まれていた。

い极わらの貯蔵中におけるトコフェロール含有量は 1 か月で $63 \%$ 減少し， $134 \mu \mathrm{g} / \mathrm{g}$ から $49 \mu \mathrm{g} / \mathrm{g}$ になり， さらに 3 か月で, $91 \%$ 減少し, $12 \mu \mathrm{g} / \mathrm{g}$ になった。この ように、い极わら中のトコフェロールは貯蔵中に急速に 減少することを藋めた。

い权の葉及び成熟したい权わらのトتフェロールは $\alpha$ ートコフェロールを主成分とし，あぶらやしの葉にも $\alpha$-トコフェロールが多く矮似している。また，米の種 皮とあぶらやしの果実の中果皮から得られるパーム油7 にトコトリエノールが多い。このように，い数及びあぶ らやしの葉及び種子（果奏）のトコフェロール及びトコ トリエノールの分布が類似している。

本研究上ほぼ同じ内享のもりを日本化学会第 45 春季年会 (昭
和 57 年: 4 月 1 日), 東宗で発表した。

本研究に対し，有益なご助言を賜ったエーザィ（株）勝井五 一郎博士並びに試料をご提供下さった 譨林水産省環境技術研究 所。杉康彦博土，東京油脂（株）一松 栄氏並びに高崎市加藤 一・郎氏に感謝します。

(昭和 59 年 8 月 2 日受理)

\section{文献}

1) H.T. Slover, Lipids, 6, 291 (1971)

2) J.F. Pennock, F.W. Hemming, J.D. Kerr, Biochim . Biophys. Res. Commun., 17, 542 (1964)

3) K. Tanabe, M. Yamaoka, A. Kato, Yukagaku, 30, 116 (1981)

4) 田辺恵三，山阎正和，田中䓬夫，加藤秋男，雨宮純子， 油化学, 31, 205 (1982)

5）加藤秋男, 田辺患三, 山阊正和, 油化学, 30, 515 (1981)

6) A. Kato, M. Yamaoka, Ab. Gapor, K.G. Berger, $J$. Am. Oil Chem. Soc., 60, 2002 (1983)

7) A. Kato, Ab. Gapor, K. Tanabe, M. Yamaoka, H. Mamuro, Yukagaku, 30, 590 (1981) 